\title{
Binding of a Polycyclic Hydrocarbon to Mouse Skin Proteins
}

\author{
HeINo Diringer and Lutz Weber \\ Max-Planck-Institut für Virusforschung, 74 Tübingen, Germany, Spemannstraße 37/39
}

(Z. Naturforsch. 27 b, 559—561 [1972] ; received February 16, 1972)

\begin{abstract}
The tritium content of the L- and K-region of commercial available tritiated 1,2,5,6-Dibenzanthracene was measured and compared with the ${ }^{3} \mathrm{H}$-release after binding of the compound to mouse skin proteins. The results exclude an addition reaction to the $\mathrm{K}$ - and L-region and favour a substitution reaction at one $\mathrm{C}$-atom.
\end{abstract}

According to the Pullman's theory the interaction of carcinogenic hydrocarbons with tissue consticuents should occur via an addition reaction at the K-region (Fig. 1) of the hydrocarbon ${ }^{1}$.

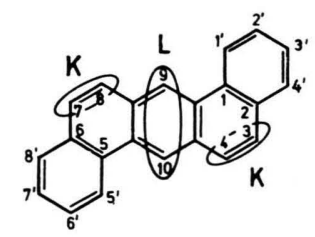

1,2,5,6-Dibenzanthracene

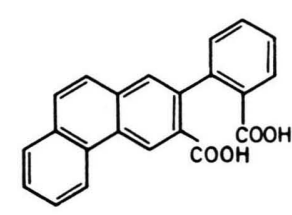

2-Phenylphenanthrene$3,2^{\prime}$-dicarboxylicacid<smiles>c1ccc2c(c1)-c1cc3ccc4ccccc4c3cc1C1OC21</smiles>

3,4-Epoxy-3,4-dihydro-1,2,5,6dibenzanthracene

Fig. 1

Theoretical considerations have taken into account an intermediate carbonium ion in this region that will react with electron rich sites within the cell ${ }^{2}$. This interaction of a carcinogen with protein or DNA is considered generally to be involved in oncogenesis. Experimental evidence for a reaction mechanism involving the K-region of the hydrocarbon in carcinogenesis is the low carcinogenic activity of the 3,4-epoxy-3,4-dihydro-1,2,5,6-dibenzanthracene in animals ${ }^{3}$. More recently the high transforming activity of epoxides on tissue culture cells has been reported ${ }^{4}$. The chemical evidence for such a reaction mechanism, the isolation of 2-phenylphenanthrene-3,2-dicarboxylic acid after binding of the carcinogen to proteins ${ }^{5}$ has been disproved ${ }^{6}$.

Requests for reprints should be sent to Dr. H. Diringer, MPI für Virusforschung, D-7400 Tübingen Spemannstr. $37 / 39$.
During in vivo studies on mouse skin with tritiated 1,2,5,6-dibenzanthrazene (DBA) it was observed that some of the tritium was metabolized to water ${ }^{7}$. Therefore, in order to get some insight into the mechanism of binding of DBA to mouse skin proteins we estimated the amount of ${ }^{3} \mathrm{H}$ in the Land K-region of ${ }^{3} \mathrm{H}-\mathrm{DBA}$ by the synthesis of the corresponding quinones and compared these values with the ${ }^{3} \mathrm{H}$-exchange after the carcinogen was bound to mouse skin proteins.

\section{Material and Methods}

The ${ }^{3} \mathrm{H}$-labelled DBA was purchased from the Radiochemical Center (Amersham). It had been labelled by the compony by ${ }^{3} \mathrm{H}$ exchange according to CROwTER et al. ${ }^{8}$.

The ${ }^{9-14} \mathrm{C}$-DBA was obtained from Mallinckrodt (Chicago). All compounds were checked for purity by thinlayer chromatography on silica plates (Merck, Germany) using hexane, benzene or various mixtures of chloroform/methanol.

In double labelling experiments both compounds were mixed. The ${ }^{14} \mathrm{C}$-label was taken as an estimate for the amount of DBA. Should anyloss of the specifically labelled 9-C-atom occur during the experiment this would show up immediately in a sharp increase of the ${ }^{3} \mathrm{H} /{ }^{14} \mathrm{C}$-ratio.

On the other hand a loss of ${ }^{3} \mathrm{H}$ will lower the ${ }^{3} \mathrm{H} /{ }^{14} \mathrm{C}$ ratio and from this decrease the exact loss of ${ }^{3} \mathrm{H}$ can be calculated as $\%$ of ${ }^{3} \mathrm{H}$ released $=100$

$$
\left(1-\frac{{ }^{3} \mathrm{H} /{ }^{14} \mathrm{C} \text { ratio end }}{{ }^{3} \mathrm{H} /{ }^{14} \mathrm{C} \text {-ratio start }}\right) \text {. }
$$

All counting was performed in $0,5 \mathrm{ml}$ soluene (Packard) with $10 \mathrm{ml}$ toluene solution (5 g PPO, $300 \mathrm{mg}$ POPOP/l) with the Packard Tri Carb 3375 using the method of external standardization (Packard manuel). Standard curves were obtained from samples containing known amounts of ${ }^{3} \mathrm{H}$-toluene respectively ${ }^{14} \mathrm{C}$-toluene and increasing amounts of the coloured unlabelled 9,10-DBA-quinone.

Channel settings of the scintillation counter were selected that no ${ }^{3} \mathrm{H}$ was measured in the ${ }^{14} \mathrm{C}$-channel 
with counting efficiencies of $45-65 \%$ for ${ }^{14} \mathrm{C}$. The efficiency for ${ }^{3} \mathrm{H}$ in the tritium channel was $25-30 \%$ with an overlap of $4-7 \%{ }^{14} \mathrm{C}$.

Samples containing high amounts of 3,4-DBA-quinone were left in daylight for a few hours. The intense colour disappeared. Counting was performed after the vials were left in the refrigerator of the scintillation counter for at least 24 hours. The counting results remained constant for at least 2 weeks.

\section{Results}

The ${ }^{3} \mathrm{H}$-content in the $\mathrm{L}$ - and $\mathrm{K}$-region of ${ }^{3} \mathrm{H}-\mathrm{DBA}$

The oxidation of tritiated DBA to the 9,10-quinone with potassium dichromate ${ }^{9}$ showed that all radioactivity was recovered in the quinone. Therefore less than $2 \%$ of ${ }^{3} \mathrm{H}$ is bound in the 9- and 10-positions (Tab. I).

\begin{tabular}{llll}
\hline & $\begin{array}{l}\text { Specific Activity }\left[\begin{array}{l}\mathrm{DPM} / \mu \text { mole }] \\
\text { DBA } \\
\text { quinone }\end{array}\right. \\
\end{array}$ & ${ }^{3} \mathrm{H}$ release \\
{$[\%]$}
\end{tabular}

Table I. Tritium content in the L-region of DBA. 1 mmole of DBA was oxidized with 1,8 mmole of potassium dichromate in $4 \mathrm{ml}$ of glacial acetic acid. The compound was recrystallized from toluene.

The 3,4-quinone was synthesized via the addition product of osmium tetroxide to give the 3,4-dihydroxy-3,4-dihydro-DBA, which was then oxidized to the quinone ${ }^{5}$ (Fig. 2). The purity of all compounds was checked by thinlayer chromatography in benzene/chloroform 7/3 (Fig. $3^{*}$ ).


Fig. 2.

The amount of tritium in the 3,4-position was estimated by oxidizing a mixture of ${ }^{3} \mathrm{H}-\mathrm{DBA}$ and 9. ${ }^{14} \mathrm{C}$-DBA. From the ${ }^{3} \mathrm{H} /{ }^{14} \mathrm{C}$ ratio of the starting material and the ${ }^{3} \mathrm{H} /{ }^{14} \mathrm{C}$-ratio of the end product the ${ }^{3} \mathrm{H}$-loss was calculated. As expected tritium was only lost in the last step of the quinone synthesis (Tab. II). There is no loss of ${ }^{3} \mathrm{H}$ due to unspecific exchange as can be seen from a kinetic experiment over twice the range of the oxydation time (Tab. III).

\begin{tabular}{lrl}
\hline Compound & ${ }^{3} \mathrm{H} /{ }^{14} \mathrm{C}-$ ratio & $\begin{array}{l}{ }^{3} \mathrm{H}-\text { relase } \\
{[\%]}\end{array}$ \\
\hline DBA & 12.03 & - \\
DBA-Osmium ester & 12.20 & - \\
DBA-3,4 dihydrodiol & 11.83 & 1.7 \\
3,4-quinone & 9.76 & 18.7 \\
\hline
\end{tabular}

Table II. Tritium release during the synthesis of DBA-3,4 quinone. Step I. $1 \mathrm{mmol}$ of DBA was stirred with $1 \mathrm{mmol}$ of $\mathrm{OsO}_{4}$ in $6 \mathrm{ml}$ dry benzene and $2 \mathrm{mmol}$ pyridine for 1 week. The product was washed with benzene. Step II. $100 \mathrm{mg}$ of the DBA-Osmium ester, $75 \mathrm{mg}$ of manitol, $23 \mathrm{mg}$ of $\mathrm{NaOH}$ were stirred for 3 days in $1,7 \mathrm{ml}$ of water and $1,7 \mathrm{ml}$ of chloroform at room temperature. The product was washed with water. Step III. $40 \mathrm{mg}$ of DBA-3,4-dihydro-3,4-diol were refluxed with $52 \mathrm{mg}$ of $\mathrm{K}_{2} \mathrm{Cr}_{2} \mathrm{O}_{7}$ in $6 \mathrm{ml}$ glacial acetic acid and $0,2 \mathrm{ml}$ water. The product was washed with glacial acetic acid, water, methanol, and ether. Compounds were purified by thinlayer chromatography as discribed in Fig. 3. Spots were detected under UV-light and extracted with methanol.

\begin{tabular}{ccl}
\hline $\begin{array}{l}\text { min. } \\
\text { reaction time }\end{array}$ & ${ }^{3} \mathrm{H} /{ }^{14}$ C-ratio & $\begin{array}{l}{ }^{3} \mathrm{H}-\text { release } \\
{[\%]}\end{array}$ \\
\hline 0 & 12.00 & - \\
3 & 10.12 & 15.6 \\
5 & 9.74 & 18.8 \\
10 & 9.80 & 18.3 \\
15 & 9.75 & 18.7 \\
20 & 9.74 & 18.8 \\
25 & 9.91 & 17.4 \\
30 & 9.73 & 18.9 \\
40 & 9.67 & 19.4 \\
\hline
\end{tabular}

Table III. ${ }^{3} \mathrm{H}$-release during the oxydation of DBA-3,4-dihydro-3,4-diol to DBA-3,4-quinone. Experimental conditions see Table II.

The exact calculations revealed a ${ }^{3} \mathrm{H}$-content of $18,5 \pm 0,3 \%$ in the K-region of DBA (Tab. IV, Fig. 4). A random distribution of ${ }^{3} \mathrm{H}$ over $12 \mathrm{C}-\mathrm{H}$ groups would give $16,7 \%{ }^{3} \mathrm{H}$ for $1 \mathrm{~K}$-region.

\section{The ${ }^{3} \mathrm{H}$-release after binding of ${ }^{3} \mathrm{H}-\mathrm{DBA}$ to protein} in vivo

The studies on the binding of the hydrocarbon to proteins were performed with 25 mice as reported earlier ${ }^{7}$. Each mouse received $100 \mu \mathrm{g}$ of ${ }^{3} \mathrm{H} /{ }^{14} \mathrm{C}$ DBA on its shaved back. After 48 the animals were sacrified, the skins were defatted, homogenized in $30 \mathrm{ml}$ of $0,1 \mathrm{M} \mathrm{NaCl}$, and after centrifugation at $5000 \mathrm{~g}$ for $1 \mathrm{~h}$ a pink supernatant was obtained.

* Figs. 3 and 4 see Table page 562 a. 
An aliquot was precipitated with 4 volumes of ethanol, the precipitate was washed $3 \times$ with $80 \%$ ethanol and ether. The ${ }^{3} \mathrm{H} /{ }^{14} \mathrm{C}$-ratio was measured in the washed precipitate and showed a tritium release of $13,2 \%$ in the bound material (Tab. V). The same data were obtained after passing the supernatant through a Sephadex G 25 coumn with $4 \mathrm{M}$ guanidinium hydrochloride prior to precipitation of the high molecular weight fraction, or by first extracting the protein from the supernatant with phenol and then precipitating it from the clear phenol phase with ethanol.

${ }^{3} \mathrm{H} /{ }^{14} \mathrm{C}$-ratio ${ }^{3} \mathrm{H}$-release $[\%]$

\begin{tabular}{llrl}
\hline Exp. I & DBA-3-4-dihydrodiol & 11.83 & - \\
& 3,4-quinone & 9.64 & $18.7+0.3$ \\
Exp. II & DBA-3-4-dihydrodiol & 10.25 & - \\
& 3,4 -quinone & 8.38 & $18.3 \pm 0.3$ \\
\hline
\end{tabular}

Table IV. Tritium content in the K-region of DBA. Experimental conditions see Table II. 15 different samples of the compounds were counted and taken for calculation.

\begin{tabular}{llcl}
\hline & & ${ }^{3} \mathrm{H} /{ }^{14}$ C-ratio & $\begin{array}{l}{ }^{3} \mathrm{H}-\text { release } \\
{[\%]}\end{array}$ \\
\hline Exp. I & $\begin{array}{l}1,2,5,6-D B A \\
\text { proteinbound compound }\end{array}$ & 13.12 & - \\
Exp. II & $1,2,5,6-D B A$ & $13.4 \pm 0.3$ \\
proteinbound compound & 6.95 & - \\
\hline
\end{tabular}

Table V. Tritium release from DBA after binding to mouse skin proteins. At least 10 different samples of the starting material and the isolated protein were counted and taken for calculations.

\section{Discussion}

These data demonstrate that metabolism of the DBA at a position different from the L-region must have occured in the protein bound compound. The loss of tritium in the in vivo experiment indicates that a simple addition reaction to any region of the

1 A. Pullman and B. Pullman, Adv. Cancer Res. 3, 117 [1955].

2 A. Dipple, P. D. Lawley, and P. Brookes, Europ. J. Cancer 4, 493 [1968].

3 B. L. van Duuren, Ann. N. Y. Acad. Sci. 163, 633 [1969].

4 P. L. Grover, P. Sims, E. Huberman,H. Marquardt, T. Kuroki, and Ch. Heidelberger, Proc. nat. Acad. Sci. USA 68, 3195 [1971].

5 P. M. Bhargava, H. J. Hadler, and Ch. Heidelberger, J. Amer. chem. Soc. 77, 2877 [1955].

6 H. Diringer and Ch. Heidelberger, Cancer Res. 29, 2127 [1969]. molecule is not the correct mechanism for the binding of DBA to proteins. In this case no tritium should have been lost. A reaction mechanism which eliminates at least 1 hydrogen is involved in the binding process. A distinct reaction mechanism which eliminates both hydrogens of the K-region has to eliminate $18,3 \%$ of the tritium content of DBA. The observed ${ }^{3} \mathrm{H}$-loss of $13,2 \%$ does not agree with such a mechanism. An addition reaction with a following incomplete elimination of tritium is unlikely. It is also not very likely that different metabolites of DBA react in different ways with the protein. There is experimental evidence that a variety of different organic carcinogenic agents all react in a very specific manner with tissue constituents ${ }^{10}$. If binding at the K-region occurs at all it is a substitution reaction at one C-atom. This possibility can not be excluded. The expected amount of tritium released in this case would be 9\% provided the radioactivity of the K-region is distributed equally in the 3- and 4-position. This could not be tested and, of course, must not necessarily be the case. Indeed the comparison of the ${ }^{3} \mathrm{H}$-content of the L- and K-region shows that the ${ }^{3} \mathrm{H}$ is not equally distributed over the DBA molecule. On the other hand it has been shown that not all carcinogenic polycyclic hydrocarbons which bind to cell constituents show metabolism at the $\mathrm{K}$ region ${ }^{11}$. Furthermore it has been demonstrated that 4-Fluoro-1,2-benzanthracene is still a potent carcinogen whereas the 3-Fluoro derivative has lost its oncogenic activity ${ }^{12}$. It seems likely therefore that the observed exchange of $13 \%$ of the ${ }^{3} \mathrm{H}$ in the DBA after binding to the protein points to a reactive center in the molecule which is different from the K-region and exchanges hydrogen more easily under the conditions of labelling.

We thank Prof. C. Heidelberger at the McArdle Laboratory for Cancer Research in Madison, Wisconsin, for a sample of $9 \cdot{ }^{14} \mathrm{C}-\mathrm{DBA}$ and Prof. F. A. ANDERER for his encouragement and interest.

7 J. G. Tasseron, H. Diringer, N. Frohwirth, S. S. Mirvish, and Ch. Heidelberger, Biochem. 9, 1636 [1970].

8 D. G. Crowter, E. A. Evans, and R. Rasdell, Chem. and Ind. 1962, 1622.

9 V. T. Oliverio and Ch. Heidelberger, Cancer Res. 18, 1094 [1958].

10 J. A. Miller, Cancer Res. 30, 559 [1970].

11 P. Sims, Biochem. Pharmacol. 16, 613 [1967].

12 J. A. Miller and E. C. Miller, Cancer Res. 23, 229 [1963]. 